\title{
Household Breeding of Sheep in the City of Korhogo: Characteristics of the Populations at the Origin of This New Practice
}

\author{
Foussata Dagnogo \\ Department of Geography, University Peleforo Gon Coulibaly, Korhogo, Côte d'Ivoire \\ Email: fouss105@yahoo.fr
}

How to cite this paper: Dagnogo, F. (2022). Household Breeding of Sheep in the City of Korhogo: Characteristics of the Populations at the Origin of This New Practice. Advances in Applied Sociology, 12, 1-10.

https://doi.org/10.4236/aasoci.2022.121001

Received: November 2, 2021

Accepted: January 14, 2022

Published: January 17, 2022

Copyright ( 2022 by author(s) and Scientific Research Publishing Inc. This work is licensed under the Creative Commons Attribution-NonCommercial International License (CC BY-NC 4.0). http://creativecommons.org/licenses/by-nc/4.0/ (c) (i) (8) Open Access

\begin{abstract}
Sheep farming has become an important activity in the north of Côte d'Ivoire, particularly, in the city of Korhogo. However, no study has yet focused on the actors of this practice in the city of Korhogo. The objective of this study was to determine the demographic characteristics of sheep breeders in the city of Korhogo as well as their motivation sources for this practice. Thus, a survey was conducted in the town of Korhogo on sheep breeders who had more than 5 animals. It was found that this activity is carried out mainly by Sénoufo and Malinké of Ivorian nationality. The age range of the population interested in this type of farming is between 31 and 80 years old, with $86 \%$ of men. Few of these farms have existed for more than 10 years. Traders and civil servants are the main actors. They are motivated not only by love and passion but also by the need to support their families.
\end{abstract}

\section{Keywords}

Household Breeding of Sheep, Korhogo, Demographic Characteristics of Sheep Breeders, Sources of Motivation

\section{Introduction}

The Ivorian economy is based on agriculture which employs $2 / 3$ of the active population. It contributes to the total Gross Domestic Product (GDP) for 34\% and to export earnings for 66\% (Mondiale, 2019). Livestock remains the developing economic activity with a contribution of around $4.5 \%$ to agricultural GDP and 2\% to total GDP (Coulibaly, 2013). However, livestock is of great importance in agricultural production systems in Mali, Senegal and Burkina Faso, where millions of people derive their income from the livestock. 
Côte d'Ivoire currently depends on the Sahelo-Sudanian region for its supply in meat (Diallo, 2007; Azokou et al., 2016). Data on food security show a coverage rate for meat and offal needs to be estimated at $26.7 \%$. Despite the efforts made by the state over several decades, national meat production still remains in deficit (55\% for meat and offal and $87.4 \%$ for dairy products) (Yabile, 2011). The northern part of the country used to be the main area for domestic ruminant breeding. Unfortunately, today very little updated and reliable information on livestock is available, especially in the central, northern and western zones of the country. These areas were severely affected by the decade of military-political crisis (2002 to 2011). However, they contributed more than $40 \%$ of the national livestock population (Bamba et al., 2020). Sheep breeding was mostly practiced in Côte d'Ivoire by rural populations. As elsewhere, land tenure is a major constraint on many livestock projects, which leads sheep breeders to hut farming practice. This practice is becoming more and more common in the cities, particularly in the Department of Korhogo. Consequently, all over the town, sheep are found in most of the city's courtyards, for breeding. It is therefore important to conduct a study to understand the real sources of motivation of this practice, and the demographic characteristics of the household breeders. The objective of this work was to study the demographic characteristics of sheep breeders in the city of Korhogo and the motivations that lead them to that practice.

\section{Material and Methods}

\subsection{Study Site}

This study was carried out in the town of Korhogo located in the north of Côte d'Ivoire. The department of Korhogo is situated between latitudes $8^{\circ} 32$ and $10^{\circ} 20$ north and between longitudes $5^{\circ} 16$ and $16^{\circ} 16$ west. The target population is represented by the sheep breeders in the town of Korhogo. They were chosen randomly in each district of the town and were also subjected to a questionnaire. The survey began with direct observation of the sheepfold. The survey was conducted from July 10 to September 15, 2021.

\subsection{Data Collection}

The technical material consisted of a questionnaire structured in several parts, including the identification of the breeder, the personnel of the farm, the infrastructure, the feeding, the motivation and the financing, a camera for pictures and a decameter for measuring the size of the breeding material. The biological material was essentially made up of the sheep found on the farms. They were of different breeds, of various physiological stages and ages.

Although the choice of herders was intended to be random in the field, it was not. Face to the mistrust of the breeders, the approach was modified (duration of the survey, location of the survey, data collection, etc.). Only those with more than five (5) animals were considered in the sampling. The languages used during the survey were Senoufo, Malinké and French. Through direct observation and the 
questionnaire, information regarding the characteristics of the farms, the feed composition, the sources of water supply, were collected. The size of the farm was measured with a meter.

\subsection{Data Analysis}

The study employed descriptive statistical methods in order to analyze the data collected. There was cross checking of the questionnaires to ensure that the questions were answered properly. The data was first divided into themes and subthemes before being analyzed. Percentages were used in the analysis and presented in a tabular form to enhance proper interpretation of the data.

\section{Results and Discussion}

\subsection{Results}

\subsubsection{Distribution of Livestock in the Districts of Korhogo}

The surveys and observations conducted in the city of Korhogo made it possible to identify sheep breeding sites in the neighborhoods and villages of the city of Korhogo, despite the influence of accelerated urbanization. A total of 84 farms were recorded in the districts and villages, with the largest number (16) observed in the Soba district. In the other districts, the number of farms varied from 1 to 12 (Table 1).

Table 1. Distribution of farmers according to zones.

\begin{tabular}{|c|c|c|}
\hline Districts and villages & Number of breeders & Percentage of breeders (\%) \\
\hline Air France & 1 & 1 \\
\hline Belle-Ville & 7 & 8 \\
\hline De la force & 1 & 1 \\
\hline Gnalélékaha & 4 & 5 \\
\hline Haoussabougou & 3 & 4 \\
\hline Kassirimé & 12 & 14 \\
\hline Kôkô & 10 & 12 \\
\hline Latonon & 1 & 1 \\
\hline Logokaha & 4 & 5 \\
\hline Markory & 4 & 5 \\
\hline Ochene & 2 & 2 \\
\hline Petit-Paris & 9 & 11 \\
\hline Sinistré & 5 & 6 \\
\hline Soba & 16 & 19 \\
\hline Tiékélézo & 5 & 6 \\
\hline Total & 84 & 100 \\
\hline
\end{tabular}




\subsubsection{Socio-Demographic Characteristics of the Breeders}

1) Distribution according to the nationality of the breeders and ethnicity

Our investigation revealed that most of the breeders (94\%) are ivorians. However, $6 \%$ of the herders are non-ivorians (Figure 1). The results of the survey revealed that the Senoufos (the dominated ethnic) are not the only people involved in this activity, although they are in the majority (67\%). The Malinké represent $30 \%$ and the Peulh are $4 \%$ (Table 2).

2) Distribution of breeders by gender, age and literacy level

Figure 2 shows the percentage of farmers by gender. According to the survey, $86 \%$ of the breeders are men and $14 \%$ are women. The majority (48\%) of the farmers surveyed are adults between the ages of 31 and 50 years. Young people represent $5 \%$ with an age between 20 and 30 years. Adults between 51 and 80 years old represent $45 \%$ of breeders (Table 3 ). Relatively to the literacy level, results showed that the proportion of literate sheep breeders in the city of Korhogo was $51 \%$ while $49 \%$ was illiterate (Figure 3 ).

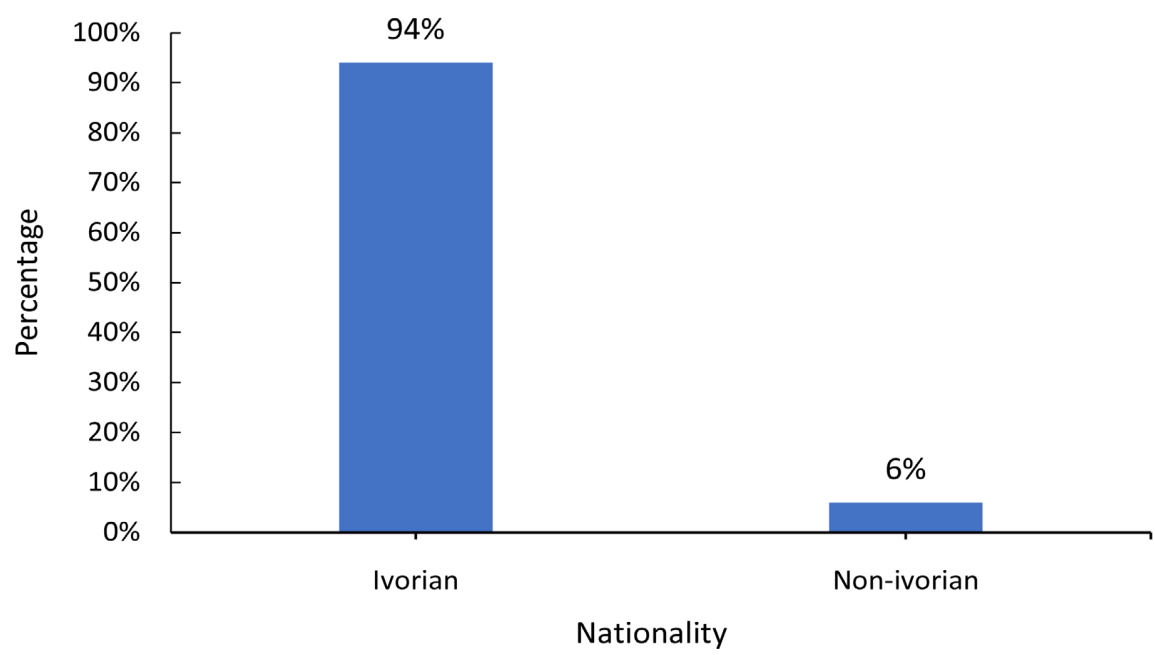

Figure 1. Percentage of breeders in function of their nationality.

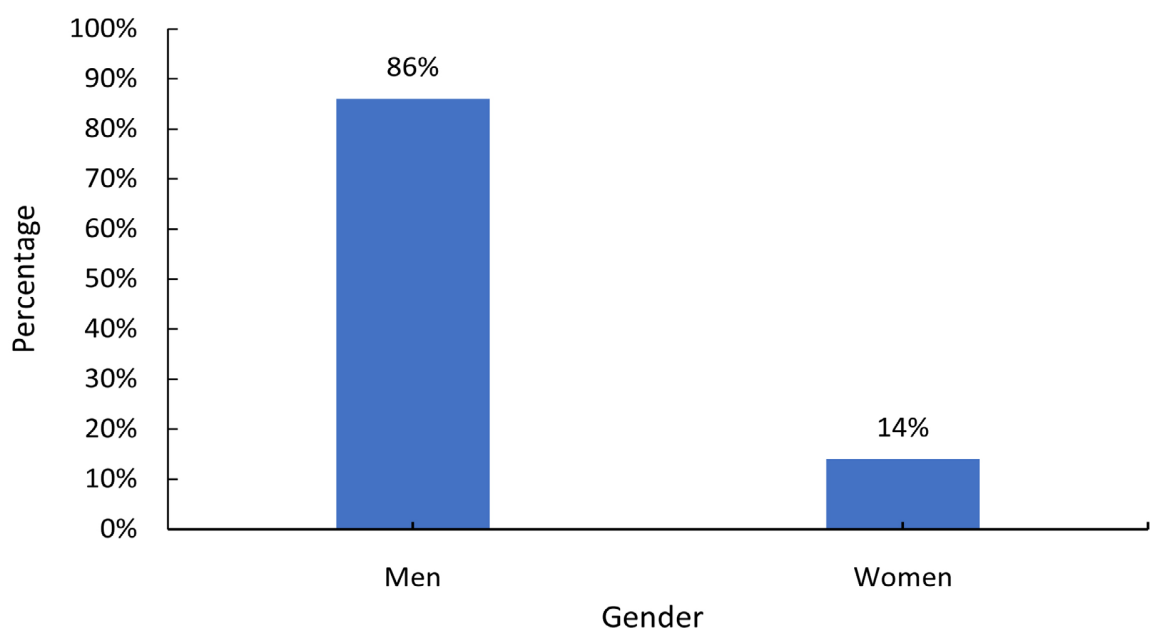

Figure 2. Distribution of farmers in function of gender. 


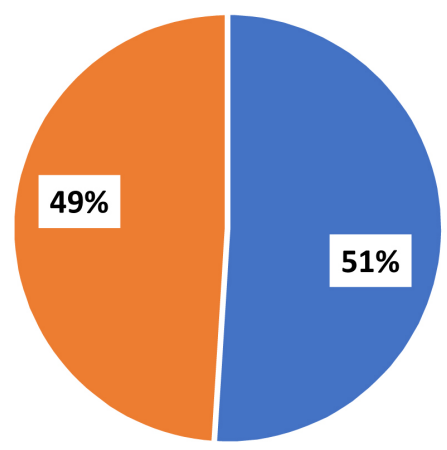

- literate

illiterate

Figure 3. Proportion of farmers by literacy level.

Table 2. Distribution of breeders according to age.

\begin{tabular}{ccc}
\hline Ethnic group & Breeders & Percentage \\
\hline Sénoufo & 56 & $67 \%$ \\
Malinké & 25 & $30 \%$ \\
Peulh & 3 & $4 \%$ \\
Total & 84 & $100 \%$ \\
\hline
\end{tabular}

Table 3. Distribution of breeders according to age.

\begin{tabular}{ccc}
\hline Age range (years) & Number of breeders & Percentage \\
\hline $20-30$ & 4 & $5 \%$ \\
$31-50$ & 40 & $48 \%$ \\
$51-80$ & 38 & $45 \%$ \\
81 and + & 2 & $2 \%$ \\
Total & 84 & $100 \%$ \\
\hline
\end{tabular}

3) Distribution of breeders according to their experience

The experience of the breeders is illustrated on Figure 4. Results showed that $58 \%$ of breeders in the city of Korhogo had between 0 and 10 years of experience; $24 \%$ had between 11 and 20 years of experience and $10 \%$ got between 21 and 30 years of experience. About $8 \%$ of the breeders had more than 30 years of experience.

\subsubsection{Socio-Economic Characteristics of the Breeders}

1) Distribution in function of activities associated to breeding

The surveys showed that sheep farming was the second activity in the active life of livestock owners in the districts and villages of the department of Korhogo. Figure 5 presents the percentages of livestock owners according to the activities associated with breeding. It was revealed that $12 \%$ of the herders practiced agricultural activities. However, $45 \%$ are traders and $43 \%$ are civil servants. 


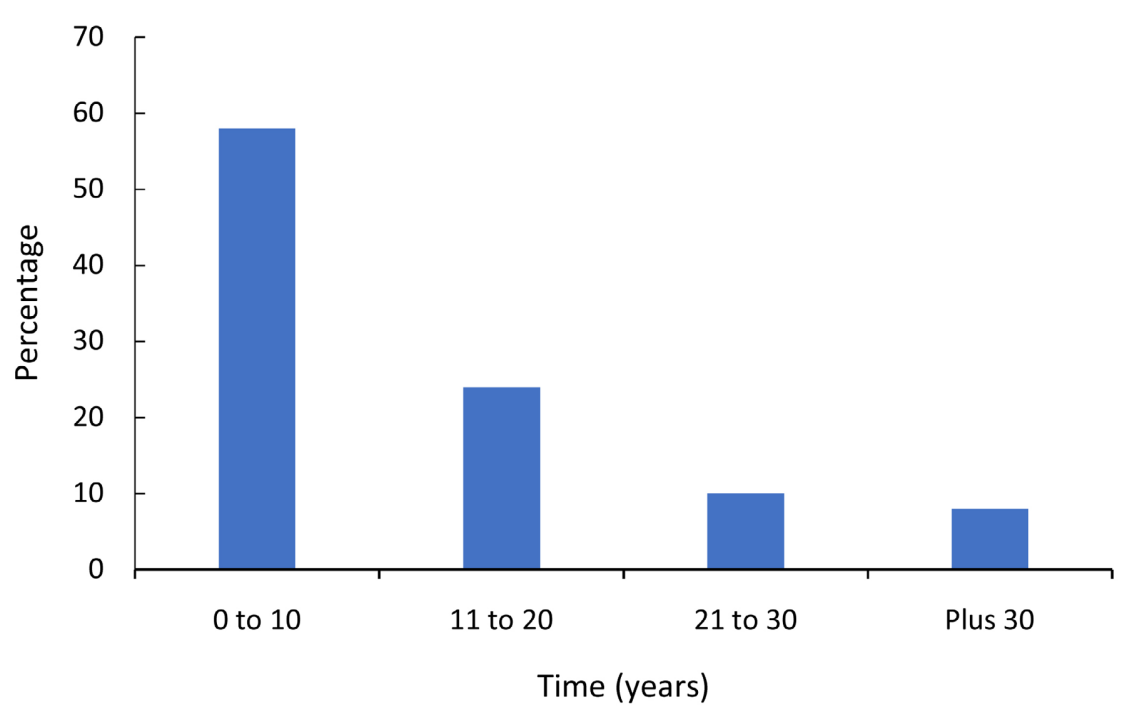

Figure 4. Distribution of farms by age.

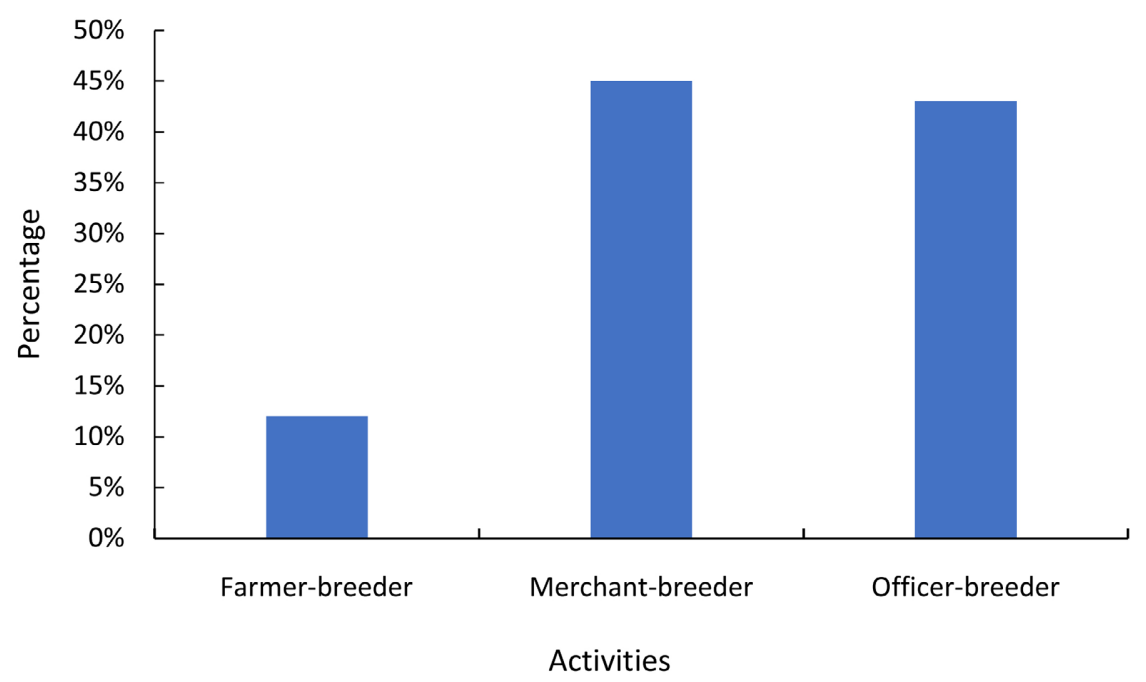

Figure 5. Distribution of breeders according to activities associated with breeding.

2) Source of motivation for breeding

In terms of the distribution of farmers according to their motivation for raising sheep, analysis of Figure 6 showed that $46 \%$ of farmers raised sheep for love and passion. Also, $45 \%$ of breeders practiced breeding to meet their needs, $7 \%$ for personal choice, while $1 \%$ practiced it to have animal for ceremonies and sacrifices.

\subsection{Discussion}

After investigating in the city of Korhogo, it was clear that the herders of Soba were the most numerous with 19.05\%. This was followed by Kassirimé (14.29\%), Kôkô (11.90\%) and Petit-paris (10.71\%). This high concentration of herders in these zones, especially in the Soba zone, could be explained by its population density. This result was similar to that of Yaye (2019) who observed that the 
- For passion $\backsim$ For needs $\backsim$ Personnal choice $\backsim$ For ceremonies and sacrifices

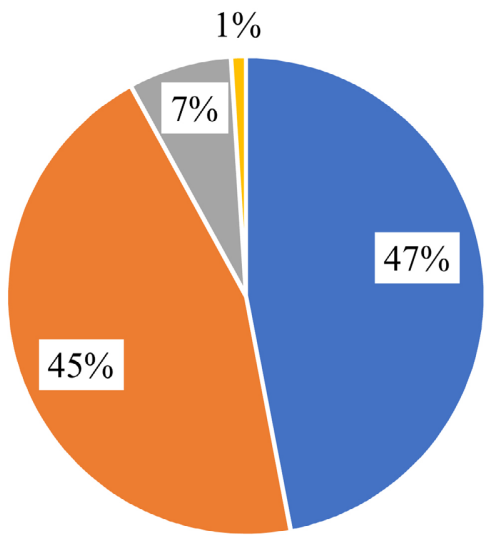

Figure 6. Distribution of breeders in function of source of motivation.

highest number of respondents in the Maradi region (55.96\% of herders) was linked to a large number of herders in the region and by the ease of access to information in the area during the study.

The investigation showed that $94 \%$ of the breeders were from Côte d'Ivoire (Ivorian) nationality when $6 \%$ were non-Ivorian. This could be justified by the awareness of the insufficient coverage of meat needs and by the income generated by the sale of sheep during the Tabaski holiday. These results are similar to those of (Touré \& Ouattara, 2001) who indicates that $76 \%$ of the sheep flocks belonged to Ivorian women. He argues that peri-urban sheep farming can provide a relief fund.

Among the sheep farmers identified in the city of Korhogo, $86 \%$ were men (adults), and the majority of these men were between 31 and 50 years old. This could be explained by the fact that in the city, women are more involved in growing and marketing food products. According to CIRAD (2019), women represent the essential link in the value chain of market gardeners in Côte d'Ivoire. Dagnogo (2021) showed that the development of market gardening is an opportunity for women empowerment in the region of poro. However, sheep farming is a man's business. These results corroborate those of (Tchouamo et al., 2005). According to these authors, small ruminant farming is not only a predominantly male activity, but also an activity carried out by older men who are married to more than one woman. Women represent only $11 \%$ of the participants in the survey.

With regard to the level of literacy, the results of our surveys showed that the proportion of literate herders in the city of Korhogo was 51\%. Similar observation was made by (Tchouamo et al., 2005) in the locality of Bafou in western Cameroon. According to their study, $76 \%$ of livestock managers went to school. This is certainly an advantage for farmers in terms of setting up health protection and monitoring the feeding of small ruminants. Contrary to herders, (Dagnogo et al., 2018) found that $85 \%$ of onions producers are illiterate in the region of Poro.

The majority of farmers in the city of Korhogo were traders (45\%), followed 
by civil servants (43\%) and farmers (12\%). Livestock farming thus occupies a secondary place in the active life of the owners. These results are contrary to those of Diomandé (2013). According to the latter, the majority of livestock owners (65\%) in Korhogo department are farmers.

The results of this study also showed that a proportion of the farmers (46\%) are motivated by the love and passion they have for sheep, $45 \%$ of the farmers practiced breeding to provide for their needs and 7\% practiced by personal choice. This could be justified by the fact that the main objective of sheep breeders is to generate income. However, $1 \%$ practiced this activity for ceremonies and sacrifices. These results corroborate those of Diomandé (2013), who states that $60 \%$ of the breeders are motivated by generating income. In addition, another $40 \%$ practiced this activity to cope with traditional ceremonies, religious sacrifices and baptisms. He states that this can be explained by the high cost of living and the numerous financial burdens of parents (children's schooling, family care, etc.). Regarding the age of the farm, the majority (58\%) of the farmers surveyed have between 0 and 10 years of experience. This was followed respectively by $24 \%$ of breeders with 11 to 20 years of experience, $10 \%$ of 21 to 30 years of experience and $8 \%$ of breeders with more than 30 years of experience. In fact, farmers use family labor to manage their farms and that could be justified by the fact that parents initiate their children to livestock farming at an early age. These results corroborate those of (Tchouamo et al., 2005), who assert that the role of children is decisive in the raising of small ruminants, and that the labor force is mainly familybased.

The observations made in each zone have allowed us to show that the herders use huts or pens as shelters for their animals. This can be explained by the fact that urbanization has led to the establishment of infrastructure for the storage of animals consisting of huts and pens with one or two rooms (one room for breeding and the other considered a storage area). These pens and huts are either open or closed with a bare floor. In these dwellings, the feeders and drinkers are often made of salvaged materials. These results are identical to those of (Boly et al., 2001), who state that the existing sheep pens are basic and limited to a fence with a few feeders. There is no sheepfold with a roof and a well-arranged opening capable of protecting the animals from bad weather and animal theft.

The survey indicated that the majority of farmers (63\%) distributed natural fodder as a staple, compared to $4.80 \%$ who distributed agro-industrial products as a staple. Also, among them, $66.7 \%$ distributed agro-industrial products, household waste, peanut bark and cooking or licking salt as supplements. This could be justified by the fact that sheep fattening is the activity most practiced by the farmers. For herders, feeding is done less and less or not at all on the rangelands to minimize theft and sudden death of animals. They have more recourse to the practice of distributing feed to the animals. In this system, family fattening is practiced by agro-breeders in rural areas (1 or 5 sheep). The animals' diet is based on crop residues and natural fodder. These results corroborate those of (Boly et al., 
2001), who confirm that fattening makes the best use of crop and household residues (bran and food residues). According to them, this type of livestock farming generates substantial income needed to pay for health care, schooling for children and the daily needs of the family. (Otte \& Upton, 2005) revealed that livestock production makes a significant contribution to the livelihoods of the poor and offers substantial scope for expansion to alleviate poverty. The animals are then supplemented with bran, agro-industrial products, but also with kitchen waste and salt or lick stone. In addition, $64 \%$ of the farmers distribute the feed three times a day. These results are different from those of (Gnanda et al., 2015). According to their results, the rate of feed distribution was on average twice a day.

\section{Conclusion}

Sheep farming is an activity that is practiced in the city of Korhogo. This activity is carried out mostly by Senufo and Malinke people of Ivorian nationality. The age range of the population involved in this activity is between 31 and 80 years old, with $86 \%$ of men. Few of these farms have been existing for more than 10 years. Traders and civil servants are the main actors. They are motivated not only by love and passion but also by the need to support their families.

\section{Conflicts of Interest}

The author declares no conflicts of interest regarding the publication of this paper.

\section{References}

Azokou, A., Achi, Y. L., \& Koné, M. W. (2016) Lutte contre les tiques du bétail en côte d'ivoire par des méthodes traditionnelles. Livestock Research for Rural Development, 28. http://www.Irrd.org/Irrd28/4/azok28052.htm

Bamba, K. L., Kouamé, A. C., Kouadio, E. K., \& Gouagoua, S. (2020). L'élevage ovin. (Ovis Aries) en côte d'ivoire: Caractéristique démographique du cheptel des localités de Touba (Ouest), Korhogo (Nord) et Bouaké (Centre). Afrique Science, 16, 8-16.

Boly, H., Ilboudo, B. J., Ouedraogo, M., Berti, F., Lebailly, P., \& Leroy, P. (2001). L'élevage du "mouton de case": Aspects techniques, socio-économique et perspectives d'amélioration au Yatenga (Burkina Faso). Biotechnology, Agronomy, Society, and Environment, 5, 201-208.

CIRAD (The French Agricultural Research Centre for International Development) (2019). Etude d'identification et d'analyse des contraintes à la production maraîchère selon les grandes zones agro-climatiques de la Côte d'Ivoire (140 p). Programme d'Appui au Développement des Filières Manioc et Maraichers en Côte d'ivoire (PRO2M), Rapport d'expertise.

Coulibaly, D. (2013). Politique de développement de l'élevage en côte d'ivoire: Direction de planification des programmes (DPP) (40 p).

Dagnogo, F. (2021). Development of Market Gardening in the Region of Poro: An Opportunity for the Empowerment of Women. International Journal of Arts and Social Science, 4, 1-8. 
Dagnogo, F., Coulibaly, S. S., Konaté, D., \& Fofana, L. (2018). Low Productivity of Onion in Côte d'Ivoire: Causes and Recommendations. International Journal of Agriculture \& Environmental Science, 5, 49-56. https://doi.org/10.14445/23942568/IJAES-V5I5P108

Diallo, Y. (2007). Les peuls, les sénoufo et l'Etat nord de la côte d'ivoire. Problème foncier et gestion du pastoralisme. Bulletin de l'APAD, 10/1995.

Diomandé, D. (2013). Caractéristique socio-économiques de l'élevage ovin villageois dans le département de Korhogo (Côte d'Ivoire) (26 p). Mémoire de licence, IGA/Université Pelefora Gon Coulibaly.

Gnanda, I. B., Nignan, M., Ouedraogo, S., N’Diaye, W. A., Traore, O., \& Sinon, B. (2015). Influence d'une Co-construction de rationnement amélioré sur les performances d'embouche ovine paysanne dans la commune rurale de korsimoro au Burkina Faso. International Journal of Biological and Chemical Sciences, 9, 1544-1556. https://doi.org/10.4314/ijbcs.v9i3.35

Mondiale, B. (2019). Au pays du cacao: Comment transformer la Côte d'Ivoire (Juillet 2019/Neuvième édition, 64 p). Groupe Banque Mondiale.

Otte, J., \& Upton, M. (2005). Poverty and Livestock Agriculture (29 p). Research Report, University of Reading.

Tchouamo, R. I., Tchoumboué, J., \& Thibault L. (2005). Caractéristiques socio-économiques et techniques de l'élevage de petits ruminants dans la province de l'ouest du Cameroun. Tropicultura, 23, 201-211.

Touré, G., \& Ouattara, Z. (2001). Elevage urbain des ovins par les femmes à Bouaké, Côte d'Ivoire. Cahier Agriculture, 10, 45-49.

Yabile, R. K. (2011). Promotion de l'agriculture vivrière et croissance économique de la Côte d'Ivoire: Quelle relation? Agronome africaine, 23, 259-272.

Yaye, A. H., Dayo, K. G., Issa, M., Mani, M., Idi, I., \& Marichatou H. (2019). Etude des pratiques d'élevage des moutons Peulh du Niger: Le Peulh blanc et le Peulh bicoulore. International Journal of Biological and Chimical Science, 13, 83-98.

https://doi.org/10.4314/ijbcs.v13i1.8 